\title{
Defoliation of a northern wheatgrass community: Above- and belowground phytomass productivity
}

\author{
JUN ZHANG AND JAMES T. ROMO
}

\begin{abstract}
Authors are former graduate student and associate professor, Dep. of Crop Science and Plant Ecology, Univ. of Saskatchewan, Saskatoon, Saskatchewan, S7N OWO.
\end{abstract}

\begin{abstract}
A defoliation study was conducted on a fair condition, clayey range site that is potentially dominated by northern wheatgrass (Agropyron dasystachyum (Hook.) Scribn.) in south-central Saskatchewan. Vegetation was subjected to a factorial experiment with an initial defoliation in early-May, June, July, or August and repeated at 2- or 6-week intervals until midSeptember in the same plots for 3 years. An undefoliated control was also included. Herbage removed, residual live, dead, total, and root phytomass were measured. Defoliation reduced all yield components, with the exception of herbage removed. Residual live grass was reduced 37,57 , and $46 \%$, respectively, in first, second, and third years; the sedge and forb components of live residual phytomass generally were not affected by defoliation. Compared to control, dead phytomass was reduced $77 \%$ in the first year, $67 \%$ in the second, and $52 \%$ in the third year across treatments. Total herbage yield across defoliation treatments ranged from 68 to $83 \%$ of control. Total live phytomass (herbage removed + residual live phytomass) in defoliated plots equaled control. Herbage removal was greatest when initially defoliated in early July and thereafter at 2-week intervals. When defoliated at 6-week intervals residual live and dead phytomass were generally greater than when herbage was removed biweekly. Yields were higher when the first defoliation was delayed and repeated at 6-week intervals. Generally, root phytomass was not different among defoliation treatments, but total belowground phytomass was reduced $30 \%$ in the $0-30-\mathrm{cm}$ depth after 3 years of defoliation. This northern mixed prairie ecosystem is sensitive to herbage removal. Maximum forage yield can be obtained if grazing is deferred until after peak growth in July.
\end{abstract}

Keywords: Agropyron dasystachyum (Hook.) Scribn., grazing, litter, mixed prairie, regrowth, roots, yield

Time and intervals of defoliation interact in complex ways on production processes and herbage yield in rangeland ecosystems. Most cool-season bunchgrasses are susceptible to clipping in late spring or during the boot-stage, whereas clipping before internode elongation may be less detrimental (Wilson et al. 1966, Ganskopp 1988). Fescue grassland is best maintained if grazed in late summer or while dormant (Willms 1991, Willms and Fraser 1992).

Frequent defoliation often reduces herbage yield (Reed and Dwyer

\footnotetext{
This research was funded by a Canadian International Development Agency grant to the Dep. of Crop Science and Plant Ecology. Univ. of Saskatchewan. The authors thank 2 anonymous reviewers for constructive comments on an earlier version.

Manuscript accepted 25 Jan. 1994
}

1971, Buwai and Trlica 1977), decreases root growth (Crider 1955) and penetration (Svejcar and Christiansen 1987), and alters rootshoot ratios (Richards 1984). When tall wheatgrass (Agropyron elongatum (Host) Beauv.) was defoliated every 4 weeks, it produced more herbage than if defoliated at 1 or 2 -week intervals (Undersander and Naylor 1987). After grazing or clipping, the amount of dead phytomass also is often severely reduced (Coupland et al. 1973, Sims et al. 1978).

Yield following clipping also varies substantially from year-toyear (Svejcar and Rittenhouse 1982, Willms 1991) because of variation in climate. Therefore, the influences of grazing on phytomass production often may be masked by the effects of climate (Hart and Samuel 1985, Archer and Smeins 1991).

Northern wheatgrass or thickspike wheatgrass (Agropyron dasystachyum (Hook.) Scribn.) is dominant in parts of the mixed prairie on the northern Great Plains in Canada (Coupland 1950). In southern Saskatchewan its dominance is best expressed on range sites with loam to clayey soils. Despite the abundance of this rhizomatous perennial, little information is available on the influence of defoliation on above- and below-ground phytomass production and distribution in the aboveground compartment. Therefore, the objectives of this study were to determine: 1) the effects of 4 initial defoliation dates and 2 intervals on the total amount of herbage removed, residual live phytomass, and dead phytomass; 2) relationships among these yield components; and 3 ) below-ground phytomass.

\section{Materials and Methods}

\section{Study Site Description}

Research was conducted at the Matador Research Station of the University of Saskatchewan, approximately $70 \mathrm{~km}$ north of Swift Current $\left(50^{\circ} 42^{\prime} \mathrm{N}, 107^{\circ} 43^{\prime} \mathrm{W}\right.$, elev. $\left.685 \mathrm{~m}\right)$. The area is located within a glacial lake plain near the northern edge of the mixed prairie (Coupland 1950). Soils are Rego Brown and Calcareous Brown Series in the Sceptre Association of the Chernozemic Brown Subground (Aridic Borolls) (Coupland et al. 1974). The study area is a clayey range site (Abouguendia 1990) with northern wheatgrass and western wheatgrass (A. smithii Rydb.) potentially producing about $75 \%$ of the total phytomass (Coupland et al. 1974). Junegrass (Koeleria cristata Pers.), green needlegrass (Stipa viridula Trin.) and low sedge (Carex eleocharis Bailey) are common while fringed sage (Artemisia frigida Willd.) is the most common non-graminoid. About 15 species of forbs are found frequently in the study area, but their distribution and abundance are variable (Coupland et al. 1973). The experiment was conducted from 1988 to 1990 in a pasture that had been heavily grazed during prior summers; range was estimated in fair condition in 1986 and 1987 (J.T. Romo pers. obs.). 
Table 1. Yield response of aboveground phytomass components $\left(\mathrm{g} \mathrm{m}^{-1}\right)$ as related to initial times and intervals of defoliationin 1988. Averages across defoliation treatments were compared to control.

\begin{tabular}{|c|c|c|c|c|c|c|c|c|c|c|c|}
\hline \multirow[b]{4}{*}{ Phytomass Category } & \multicolumn{6}{|c|}{$\begin{array}{l}\text { Defoliation treatments } \\
\text { Initial defoliation (D) }\end{array}$} & & & \multicolumn{3}{|c|}{ Contrast } \\
\hline & \multicolumn{2}{|c|}{ May } & \multicolumn{2}{|c|}{ Jun. } & \multicolumn{2}{|c|}{ Jul. } & \multicolumn{2}{|c|}{ Aug } & \multirow[t]{3}{*}{$\mathbf{L S D}^{1}$} & \multirow{2}{*}{\multicolumn{2}{|c|}{ Defoliation vs. Control $^{2}$}} \\
\hline & \multirow[b]{2}{*}{ 2-wk } & \multirow[b]{2}{*}{ 6-wk } & \multirow[b]{2}{*}{ 2-wk } & \multicolumn{3}{|c|}{ Defoliation interval (I) } & & & & & \\
\hline & & & & 6-wk & 2-wk & 6-wk & 2-wk & 6-wk & & & \\
\hline Herbage removed & -3 & - & 一 & - & - & - & - & 一 & & - & - \\
\hline \multicolumn{12}{|l|}{ Residual livec } \\
\hline Grasses & 4.5 & 9.3 & 6.9 & 8.5 & 7.6 & 6.0 & 7.6 & 9.9 & 1.7(DxI) & 7.5 & $11.9 * * *$ \\
\hline Others & 5.1 & 7.2 & 8.9 & 6.2 & 12.2 & 7.8 & 11.6 & 11.7 & $3.3(\mathrm{D})$ & 8.8 & $16.7^{* * *}$ \\
\hline Total & 9.6 & 16.5 & 15.9 & 14.7 & 19.8 & 13.8 & 19.1 & 21.6 & 5.1(DxI) & 16.4 & $28.6^{* *}$ \\
\hline Dead Phytomass & 19.7 & 22.1 & 15.6 & 23.0 & 22.8 & 23.6 & 31.1 & 27.0 & $4.3(D)$ & 23.1 & $29.9^{* *}$ \\
\hline Total Herbage Yield & 29.4 & 38.6 & 31.4 & 37.7 & 42.6 & 37.4 & 50.2 & 48.6 & 6.7(D) & 39.5 & $58.4^{* * * *}$ \\
\hline
\end{tabular}

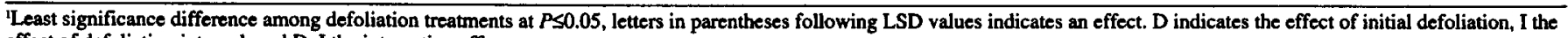
effect of defoliation interval, and DxI the interaction effect.

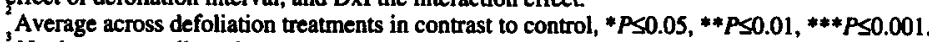

No data were collected.

Annual precipitation data were obtained from Beechy $\left(50^{\circ} 46^{\prime} \mathrm{N}\right.$, $107^{\circ} 19^{\prime} \mathrm{W}$, elev. $670 \mathrm{~m}$ ) approximately $40 \mathrm{~km}$ northeast of the study site. In 1988 precipitation was only $70 \%$ of the 50 -year mean of $373 \mathrm{~mm}$, while in 1989 and 1990 it was $106 \%$ and $113 \%$ of the long-term average.

\section{Experimental Design and Sampling Methods}

A $50 \times 50 \mathrm{~m}$ exclosure was established and 8 clipping treatments with 4 initiation dates and 2 intervals, and an undefoliated control were replicuted 4 times in a randomized-complete-block design. Plots were $5 \times 6 \mathrm{~m}$ with a $1-\mathrm{m}$ buffer maintained on all sides. Plots were defoliated by mowing to a $5-\mathrm{cm}$ stubble with a Jari sickle mower and all harvested plant material was collected. After plots were initially defoliated in early May, June, July, or August, they were defoliated again at 2- or 6-week intervals until mid-September of each year. Treatments were repeated on the same plots each year.

\section{Aboveground Phytomass}

Plant materials collected at each defoliation were summed through the season to estimate total herbage removal. In 1988, an extremely dry growing season, plants were usually less than $5 \mathrm{~cm}$ tall and no plant material was collected at most defoliation events. Therefore, data for total herbage removed in 1988 are not presented. Plant material, collected in 1989 and 1990, was separated into grasses, fringed sage, and forbs. Low sedge was generally shorter than the $5 \mathrm{~cm}$ defoliation height, thus it escaped defoliation and was not collected. Two $0.25 \mathrm{~m}^{2}$ quadrants were clipped in each plot at ground level in midSeptember each year to determine residual phytomass. The live residual phytomass in 1989 and 1990 was divided into grasses, low sedge, fringed sage, and forbs. Dead residual phytomass was not separated into species groups, and ground litter was not collected. Total herbage yield is the summation of total herbage removed, live residual, and dead phytomass. All samples were oven-dried at $80^{\circ} \mathrm{C}$ for at least $\mathbf{4 8}$ hours immediately after harvest and weighed.

\section{Belowground Phytomass}

On 26 September 1989 and 1990, a soil corer (8-cm diameter x 15 $\mathrm{cm}$ long) was used to remove a core of underground plant phytomass for the $0-15$ and $15-30 \mathrm{~cm}$ soil depths in each plot. Shoots and dead material were removed from the surface of the cores, and the underground plant material was separated from the soil by soaking each core in water for at least 12 hours. These samples were hand washed over a soil screen and sieved through a 32-mesh screen. The phytomass in the $0-15 \mathrm{~cm}$ cores was further separated into crowns and rhizomes of northern wheatgrass and low sedge, and a fine root fraction in which species could not be identified. Samples were oven dried at $80^{\circ} \mathrm{C}$ for 48 hours and weighed.

\section{Data Analysis}

The effects of defoliation regimes on aboveground and root phytomass were compared to control by linear contrasts with the SAS general linear model procedure (SAS 1985). The effects of time of the initial defoliation and defoliation interval were analyzed with a factorial analysis of variance. Where significant effects were detected $(P \leq 0.05)$, Least Significant Difference (LSD) was used to separate treatment means (Snedecor and Cochran 1980). Root phytomass in each depth was within samples. Regression analysis was used to examine relationships among yield components in 1989 and 1990 (Snedecor, and Cochran 1980).

\section{Results}

\section{Defoliation Effects on Aboveground Productivity 1988}

Defoliation reduced all yield components compared to control in 1988 (Table 1). At the end of the growing season, residual grass phytomass across defoliation treatments averaged $63 \%$ of control, dead phytomass was $77 \%$, and total yield averaged $68 \%$ of the check. The interaction of dates of initial defoliation intervals affected residual grass and total live residual phytomass. When defoliated at 6week intervals, residual phytomass of grasses was generally greater than when defoliated every 2 weeks, except when first defoliated in early July and biweekly thereafter. When herbage was removed biweekly, residual grass phytomass was greater when initially defoliated after May. With the 6-week interval residual grass phytomass was greater when first defoliated in May or August. Delaying the initial defoliation generally led to greater residual phytomass in other species, dead phytomass, and total herbage yield, with productivity greatest when first defoliated in August. 
Table 2. Yield response of aboveground phytomass components $\left(\mathrm{g} \mathrm{m}^{-7}\right)$ as related to initial time and intervals of defoliationin 1989 . Averages across defoliation treatments were compared to control.

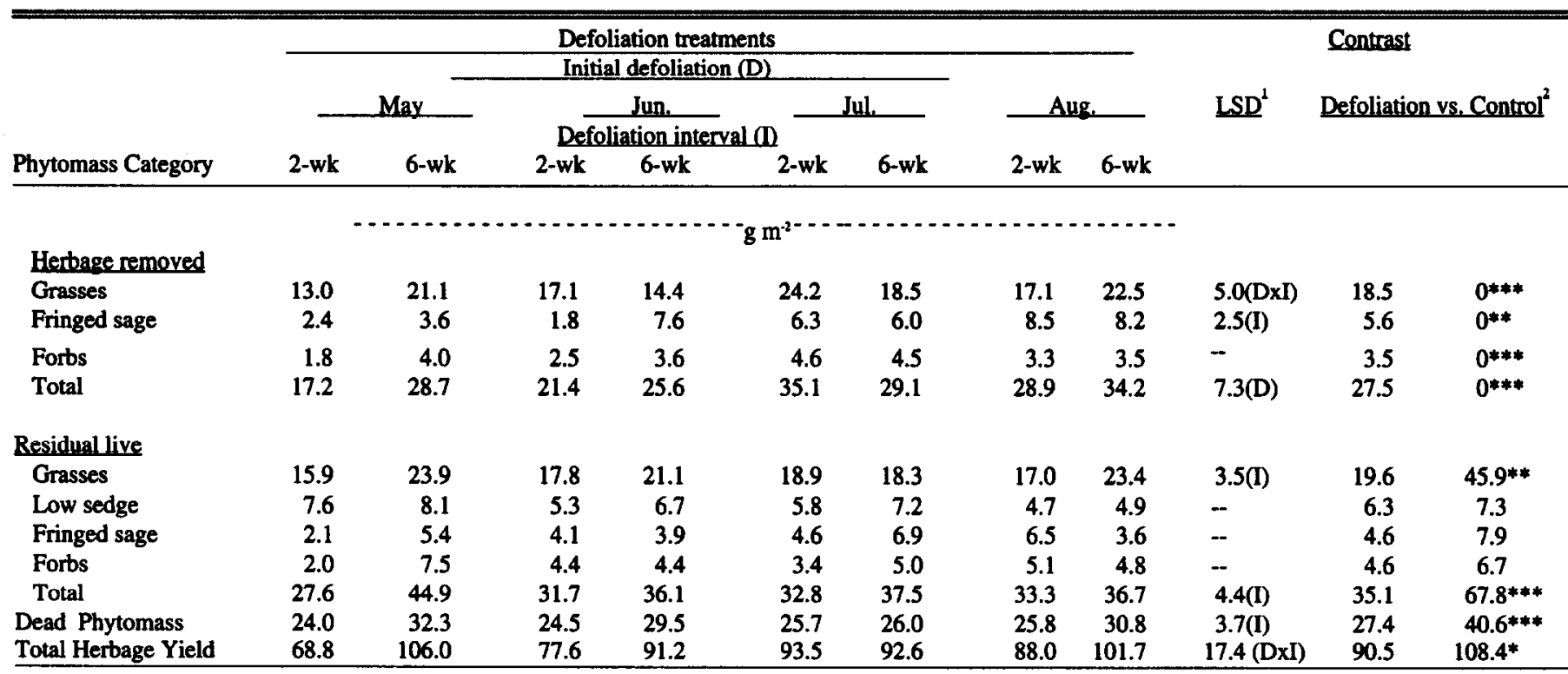

' Least significance difference among defoliation treatments at $P \leq D .05$, letters in parentheses following $L S D$ values indicates an effect. $D$ indicates the effect of initial defoliation, I the effect of defoliation interval, and DxI the interaction effect, and indicates no effect.

Average across defoliation treatments in contrast to control, $* P \leq 0.05, * * P \leq 0.01, * * * P \leq 0.001$

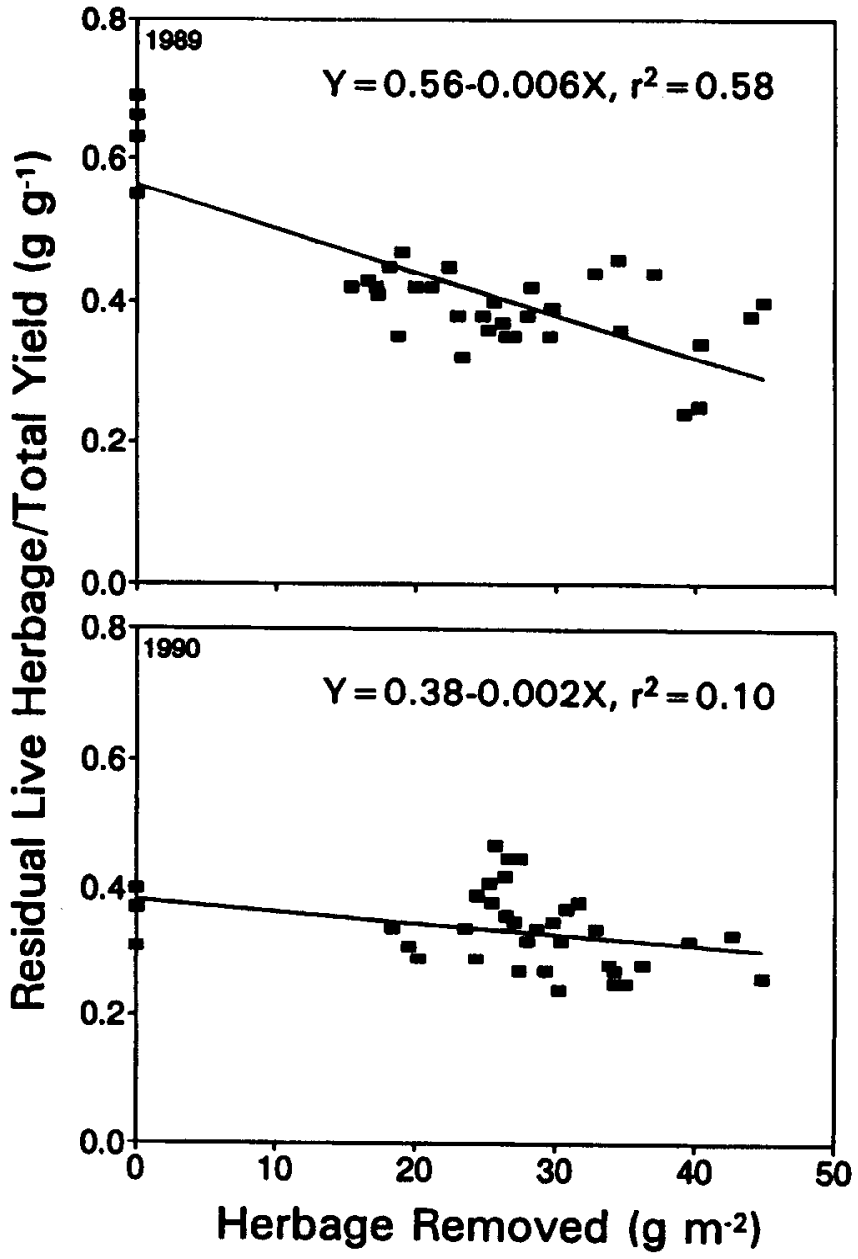

Fig. 1. Relationship between the fraction of residual live phytomass and total herbage removed in 1989 and 1990.

\section{9}

Grasses accounted for $68 \%$ of the total herbage removed across defoliation treatments with the most removed when initially defoliated in July and then every 2 weeks (Table 2). More fringed sage was removed by defoliation every 6 weeks than at 2-week intervals. Total herbage removed was greatest when defoliation was begun in July or August. At the end of the 1989 growing season, the residual grass phytomass in the defoliation treatments was on average $43 \%$ of control. The residual phytomass of all species was reduced $48 \%$ compared to control. Relative to control, dead phytomass and total herbage yield across defoliation treatments were reduced an average of 33 and $17 \%$, respectively. Residual phytomass of low sedge, fringed sage, or forbs were not significantly different among defoliation treatments at the end of growing season. Generally when harvested at 6-week intervals the residual grass, total, and dead phytomass were greater than under the biweekly defoliation. With the exception of the initial defoliation in July, total herbage yield was greater with rest periods of 6 weeks between defoliation than with 2 weeks rest.

\section{0}

The grass phytomass removed by defoliation in 1990 also followed the same pattern as in 1989. When first defoliated in July, the most fringed sage and forbs were removed. Total herbage removal was greatest when defoliated in July and then every 2 weeks (Table 3). Compared to control the same pattern of defoliation effects expressed in 1989 were also observed in 1990 with reductions of $47,31,48$, and $25 \%$, respectively, in residual grass, total residual, dead phytomass, and total herbage yield. Residual phytomass of grasses was affected by the interaction of dates of initial defoliation and intervals and was greatest when defoliated in May or August and then every 6weeks. However, when first defoliated in June or July, residual grass phytomass was similar between 2- and 6-week intervals. Dead phytomass and total herbage yield were greater when defoliated at 6week intervals compared to biweekly. 
Table 3. Yield response of aboveground phytomass components $\left(\mathrm{g} \mathrm{m}^{-7}\right)$ as related to initial times and intervals of defoliation in 1990 . Averages across defoliation treatments were compared to control.

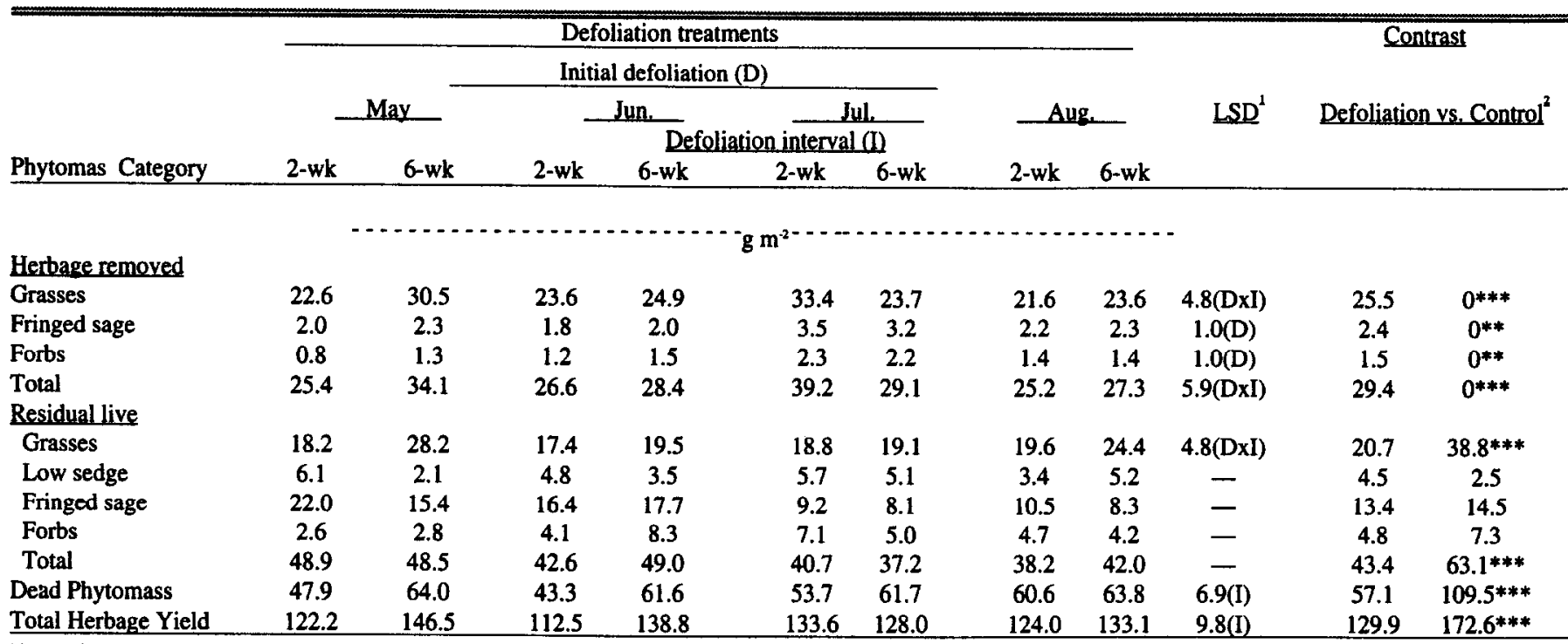

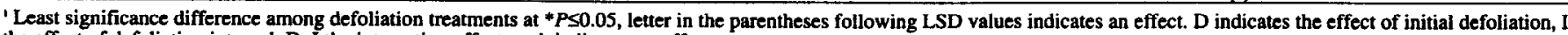
the effect of defoliation interval, DxI the interaction effect, and indicates no effect.

${ }^{2}$ Average across defoliation treatments in contrast to control, ${ }^{*} P \leq 0.05, * * P \leq 0.01, * * * P \leq 0.001$.

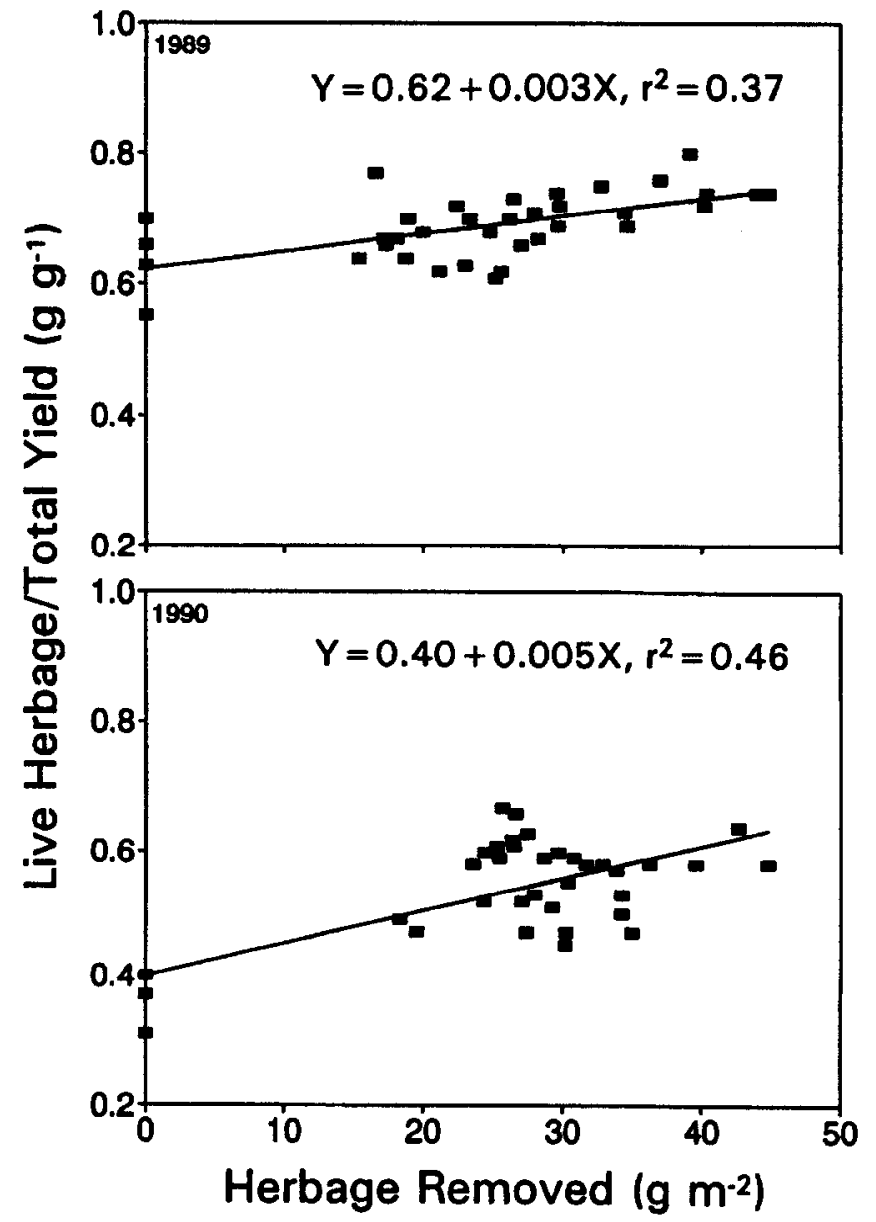

Fig. 2. Relationship between the proportion of live herbage in total yield and total herbage removed in 1989 and 1990.

\section{Relationships Among Aboveground Phytomass Components}

As herbage was removed, the proportion of live plant tissue remaining in the canopy declined (Fig. 1). When harvested phytomass was added to residual phytomass, the total live phytomass across defoliation treatments was similar to control in 1989 and 1990. Therefore, the proportion of live plant material in the total yield was greater with clipping than in the control in both years. As more phytomass was removed, the proportion of live material in the total yield also increased (Fig. 2). Dead phytomass did not decrease as the absolute amount of phytomass removed by defoliation increased, and greater tissue removal was not directy responsible for the net loss of dead phytomass in $1989\left(r^{2}=0.02, P=0.39\right)$ and 1990 $\left(r^{2}=0.02, P=0.48\right.$ ).

\section{Defoliation Effects on Belowground Phytomass}

Although a trend of reduced belowground phytomass relative to the control was apparent in every category at both depths in 1989, these differences were not significant (Table 4). The frequency and initial timing of defoliation interactively affected crown phytomass of northern wheatgrass, with crowns being heavier when herbage was removed every 6 weeks compared to 2 weeks, except when first defoliated in August. Rhizome weights of northern wheatgrass were greater when defoliated at 6-week intervals than biweekly.

In 1990, all phytomass categories except the crown and rhizome weights of low sedge were severely reduced by defoliation (Table 4). Crown and rhizome weights for northern wheatgrass were reduced 42 and $55 \%$ by defoliation, respectively. Weights of fine roots were reduced $24 \%$ in the $0-15 \mathrm{~cm}$ and $48 \%$ in the $15-30 \mathrm{~cm}$ depths compared to control. The total mass of roots and rhizomes in $0-30 \mathrm{~cm}$ depth was reduced $31 \%$ by defoliation. The date of the initial defoliation interacted with the interval of defoliation for low sedge rhizomes, with rhizomes heavier with the 6-week interval than the 2week interval in July and August. Rhizomes were heavier when plants were initially defoliated in May or June and then biweekly than every 6 weeks. 
Table 4. Weights $\left(\mathrm{g} \mathrm{m}^{-2)}\right.$. of crowns and rhizomes of northern wheatgrass and low sedge, the fine root fraction, and total mass in the 0-15 $\mathrm{cm}$ and $15-30$ $\mathrm{cm}$ depths of the soil profile in late September 1989 and 1990 . Average across clipping treatments were compared to control.

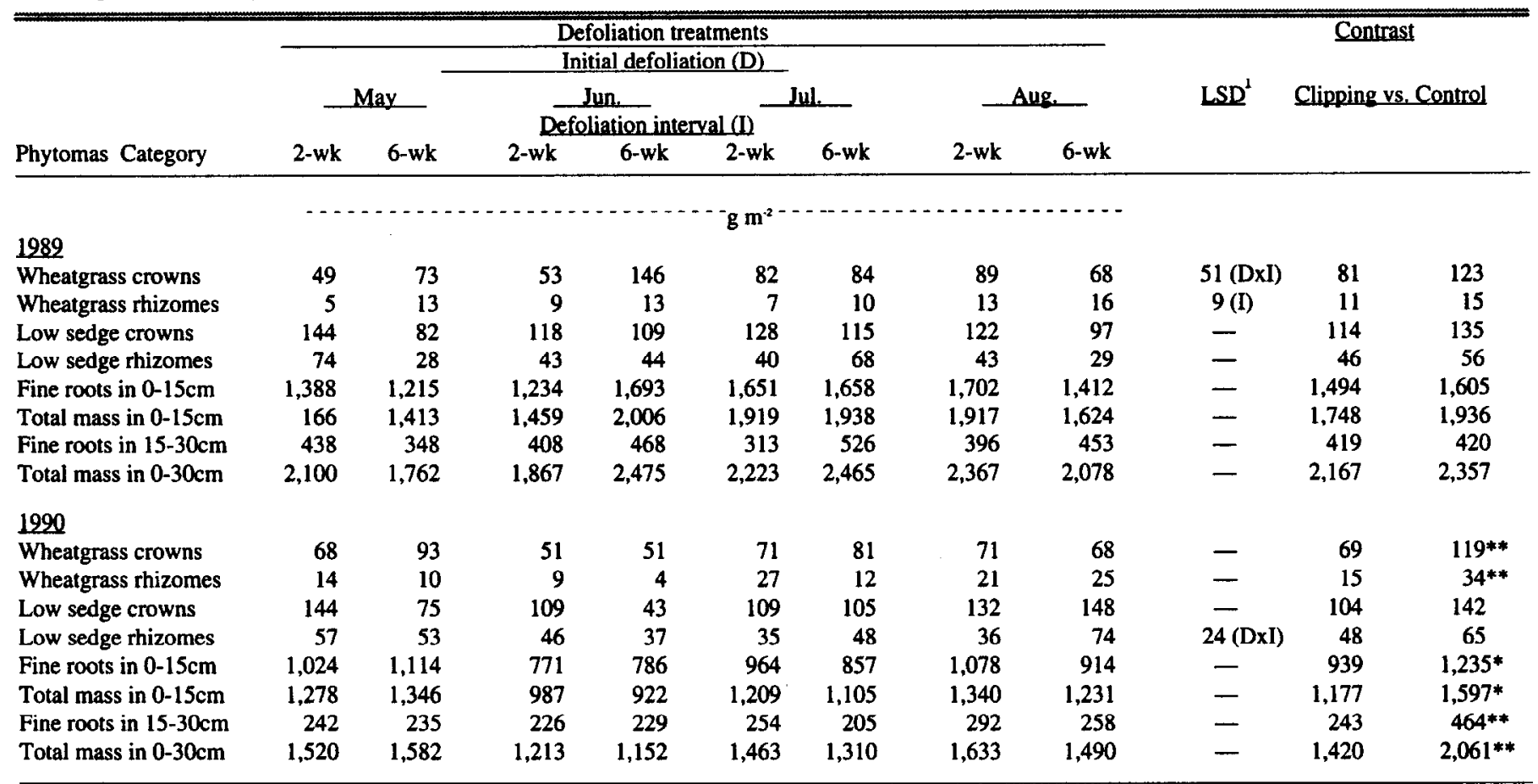

'Least singificance difference among clipping treatments. at PSO.05. Letters in parentheses following LSD values indicates an effect. $D$ indicates the effect of initial harvest, I the effect of harvest interval, DxI the interaction effect, and indicates no significant difference between treatments.

${ }^{2}$ Average across clipping treatments in contrast to control, $* P \leq 0.05 * * P \leq 0.01, * * * P \leq 0.001$.

\section{Discussion}

Most defoliation studies are conducted on plants that have received prolonged rest periods or on rangeland that is in excellent condition. Results of these studies provide information on how vigor of plants declines with herbage removal. However, because less than $25 \%$ of the rangeland in southern Saskatchewan is in good to excellent condition (Romo, unpub. data), we chose to examine responses of vegetation that had been heavily grazed and were representative of the condition of large tracts of rangeland. By conducting studies on deteriorated range, beneficial effects of defoliation regimes might reflect growth and productivity of plants that should indicate how previously grazed vegetation responds to altered grazing management.

Repeated defoliation reduced the total herbage phytomass compared to control as shown elsewhere (Reed and Dwyer 1971, Buwai and Trlica 1977). The effects of the initial timing and frequency of defoliation influenced yield components within years, but these impacts were not consistent between years. As a result conclusive statements cannot be made regarding the influences of initial timing and frequency of defoliation on relative responses of yield components in this northern mixed prairie ecosystem. These variable responses are attributed to differences in environmental conditions between years, the cumulative effects of defoliation in preceding years, or both.

When total herbage removed and residual phytomass components were combined, the total yield of live plant material was similar to control in 1989 and 1990. Thus, the discrepancies in total herbage phytomass between control and defoliation treatments can be attributed to variances in dead phytomass. Increased removal of tissue was not directly responsible for the net loss of dead phytomass in 1989 and 1990 . These differences may have been caused by reduced senescence and transfer of leaves to the dead phytomass following defoliation (McNaughton 1979, Caldwell et al. 1981, Li and Redmann 1992) and modification of the microenvironment which increased decomposition of dead plant materials (Naeth et al. 1990). As a consequence, the proportion of total live phytomass in the total yield was greater with increased herbage removal.

The greatest amount of grass was removed when first defoliated in early July and every 2 weeks. Because these grasses are $C_{3}$ species, they usually produce maximum growth by July. Harvesting in July removes the maximum amount of phytomass before it is transferred to the dead phytomass and litter compartments. However, annual removal of peak amounts of phytomass is not recommended to maintain forage productivity in northern mixed prairie. Allowances must be made to allow for transfer of phytomass to the litter because litter plays critical roles in forage production (Willms et al. 1986, 1993) and the hydrologic cycle (Naeth et al. 1991a, b).

After herbage removal plants often allocate more phytomass to shoot growth than other parts (Santos and Trilica 1978, Burleson and Hewitt 1982, Painter et al. 1989). Defoliation of northern wheatgrass also increased tillering and longevity of tillers (Zhang 1992). Because plants compensated for loss of herbage by initiating tillering, the absolute amount of herbage removed and the proportion of herbage removed in total yield both increased. This regrowth of shoots apparently had a cumulative negative effect on residual live phytomass, roots, and crowns as reflected in the substantial reduction of their weights after 3 years of defoliation. In a greenhouse study, $\mathrm{Li}$ and Redmann (1992) reported that a single clipping of northern wheatgrass substantially reduced crown phytomass relative to the control.

Lack of responses in root phytomass to herbage removal in 1989 . the second year of study, suggests that plants may have attempted to maintain their root systems in coping with defoliation. Richards 
(1984), however, proposed that maintenance of roots following defoliation may reduce the carbon that can be invested in regrowth of shoots and may affect the plant's grazing tolerance. After 3 years of defoliation in the present study, root phytomass declined dramatically, presumably reflecting cumulative effects of defoliation and a carbon deficit (Caldwell 1984). The reduction in root phytomass observed for northern wheatgrass in 1990 may have reduced its competitive position in the community and may partially explain its diminished dominance.

\section{Management Implications}

The similarity in total live yield across defoliation treatments at 2or 6-week intervals and control should not be interpreted that this northern mixed prairie ecosystem can support multiple periods of grazing. As evidenced by the significant reductions in total herbage yield, rhizome and root phytomass, this range can be quickly (in the present study 3 years) damaged by repeated herbage removal, regardless of the timing. Six weeks or less of rest following grazing was an inadequate recovery period for this range. Zhang (1992), however, concluded that aboveground standing crop and belowground phytomass in this grassland can recover with 2 to 3 years of complete rest.

Continued interruption of the transfer of dead phytomass into litter could result in unsustainable production. Therefore, this grassland probably should be grazed only once each year and the timing of grazing should be deferred until peak growth is reached, usually after July.

\section{Literature Cited}

Abouguendia, Z.M. 1990. A practical guide to planning for management and improvement of Saskatchewan rangeland-Range plan development. New Pastures and Grazing Technologies Project. Saskatchewan Rural Development,. Regina, Sask.

Archer, S., and F.E. Smeins. 1991. Ecosystem-level processes, p. 109139. In : R.K. Heitschmidt and J.W. Stuth (eds.), Grazing management: An ecological perspective. Timber Press, Portland, Ore.

Burleson, W.H., and G.B. Hewitt. 1982. Response of needle-and-thread and western wheatgrass to clipping by grasshoppers. J. Range Manage. 35:223226.

Buwai, M., and M.J. Trlica. 1977. Multiple clipping effects on herbage yield, vigor, and total nonstructural carbohydrates of five range species. J. Range Manage. 30:164-171.

Caldwell, M.M. 1984. Plant requirements for prudent grazing, p. 117-152. In: National Research Council/National Academy of Sciences, Developing strategies for rangeland management. West view Press, Boulder, Colo

Caldwell, M.M., J.H. Richards, D.A. Johnson, R.S. Nowak, and R.S Dzurec. 1981. Coping with herbivory: Photosynthetic capacity and resource allocation in 2 semiarid Agropyron bunchgrasses. Oecologia 50:14-24.

Coupland, R.T. 1950. Ecology of mixed prairie in Canada. Ecol. Monogr. 20:271-315.

Coupland, R.T., E.A. Ripley, and P.C. Robin. 1973. Description of sites: I. Floristic composition and canopy architecture of the vegetative cover. Matador Project Tech. Rep. No. 11. Univ. of Saskatchewan. Saskatoon, Sask.

Coupland, R.T., J.R. Willard, and E.A. Ripley. 1974. Summary of activities, 1967-1974. Matador Project Tech. Rep. No. 69. Univ. of Saskatchewan. Saskatoon, Sask.

Crider, F.J. 1955. Root-growth stoppage resulting from defoliation of grass. USDA-SCS Tech. Bull. No. 1102. Washington, D.C.

Ganskopp, D.C. 1988. Clipping of Thurber needlegrass: herbage and root responses. J. Range Manage. 41:471-476.

Hart, R.H., and M.J.Samuel. 1985. Precipitation and herbage production on southeastern Wyoming range sites. J. Range Manage. 38:522-525.

Li, Y.S., and R.E. Redmann. 1992. Growth response to ammonium-N, nitrate- $\mathrm{N}$ and clipping in Agropyron dasystachyum from the Canadian mixed grassland. Amer. Midl. Natur. 127:300-308.
McNaughton, S.J. 1979. Grazing as an optimization process: Grass-ungulate relationships in the Serengeti. Amer. Natur. 113:691-703.

Naeth, M.A., A.W. Bailey, D.S. Chanasyk, and R.T.Hardin. 1991a. Water holding capacity of litter and soil organic matter in mixed prairie and fescue grassland ecosytems of Alberta. J. Range Manage. 44:13-17.

Naeth, M.A., A.W. Bailey, D.J. Pluth, D.S. Chanasyk, and R.T. Hardin. 1991b. Grazing impacts on litter and soil organic matter in mixed prairie and fescue grassland ecosystems of Alberta. J. Range Manage. 44:7-12.

Naeth, M.A., D.J. Pluth, D.S. Chanasyk, A.W. Bailey, and A.W. Fedkenheuer. 1990. Soil compacting impacts of grazing in mixed prairie and fescue grassland ecosystems of Alberta. Can. J. Soil Sci. 70:157-167.

Painter, E.L., J.K. Detling, and D.A. Steingraeber. 1989. Grazing history, clipping, and frequency-dependent competition: Effects on 2 North American grasses. Amer. J. Bot. 76:1368-1379.

Reed, J.L., and D.D. Dwyer. 1971. Blue grama response to nitrogen and clipping under 2 soil moisture levels. J. Range Manage. 24:47-51.

Richards, J.H. 1984. Root growth response to defoliation in two Agropyron bunchgrasses: Field observations with an improved root periscope. Decologia 64:21-25.

Santos, G.L., and M.J. Trlica. 1978. Clipping effects on production and carbohydrate reserves of blue grama and western wheatgrass, p. 384-386. In: D.N. Hyder (ed.) Proc. 1st Int. Rangeland Congress. Soc. Range Manage., Denver, Colo.

SAS (Statistical Analysis System) 1985. SAS user's guide: Statistics. 5th edition. SAS Institute Inc., Cary, N.C.

Sims, P.L. J.S. Singh, and W.K. Lauenroth. 1978. The structure and function of ten western North American grasslands: I. Abiotic and vegetational characteristics. J. Ecol. 66:251-285.

Snedecor, G.W., and W.C. Cochran 1980. Statistical methods. Iowa State Univ. Press, Ames, Iowa.

Svejcar, T., and S. Christiansen. 1987. The influence of grazing pressure on rooting dynamics of Caucasian bluestem. J. Range Manage. 40:224-227.

Svejcar, T.,and L.R. Rittenhouse. 1982. Standing crop and vigor of defoliated Russian wildrye in southern Colorado. J. Range Manage. 36:594-597.

Undersander, D.J., and C.H. Naylor. 1987. Influence of clipping frequency on herbage yield and nutrient content of tall wheatgrass. J. Range Manage. 40:31-35.

Willms, W.D. 1991. Cutting frequency and cutting height effects on rough fescue and Parry oatgrass yields. J. Range Manage. 39:536-540.

Willms, W.D., and J. Fraser. 1992. Growth characteristics of rough fescue (Festuca scabrella var. campertris) after 3 years of repeated harvesting at scheduled frequencies and heights. Can J. Bot. 70:2125-2129.

Willms, W.D., S.M. McGinn, and J.F. Dormarr. 1993. Influence of litter on herbage production in the mixed prairie. J. Range Manage. 46:320-324

Willms, W.D., S. Smoliak, and A.W. Bailey. 1986. Forage production following litter removal on Alberta native rangelands. J. Range Manage. 39:536-540.

Wilson, A.M., G.A. Harris, and D.H. Gates. 1966. Cumulative effects of clipping on yield of bluebunch wheatgrass. J. Range Manage. 19:90-91.

Zhang, J. 1992. Vegetation responses to rest and multiple clipping regimes in an Agropyron dasystachyum dominated grassland. Ph.D. Diss., Univ. of Saskatchewan, Saskatoon, Sask. 